\title{
Pidana Kerja Sosial Dalam Membatasi Kelebihan Penghuni Di Lembaga Pemasyarakatan
}

\author{
Ahmad Fajri \\ Fakultas Hukum Universitas Islam Indonesia Yogyakarta \\ Jln. Cik Di Tiro No. 1 Yogyakarta. \\ ahmadfajri1117@yahoo.com
}

\begin{abstract}
Correctional Institutions (Lapas) that suffer from excess occupants continue to occur throughout the territory of Indonesia. Based on the data from the Directorate General of Corrections, as of January 2019, excess occupants in Indonesian penitentiaries have reached 101\%. This is dangerous from various sides, from the health to psychology. Therefore, this study was conducted to analyze the provisions of social work penalties in limiting the excess occupants in penitentiaries based on criminal theory and criteria of criminal conduct that could be subject to social work as criminal sanctions. This research is a normative study that examines written law from the aspects of theory, history, philosophy, and comparison, using a conceptual and juridical approach. Based on an analysis of the formulation of the problem, this study concludes, first, with the suitability of social sanction and criminal theory, social sanction has the prospects to be applied in Indonesia. In fact, if its role is very effective and efficient in achieving the goal of punishment, it does not rule out the possibility of a social sanction to be a single principal and can be applied to serious offenses and as a condition for clemency to be applied. That is because the advantages of social sanctions, both in terms of its humanistic and economic approach. Second, For its criteria, social work sanction functions as an alternative to a short/mild prison sentence, less than six months, and a first category of light fines, which is a maximum of ten million rupiah. In the draft of 2017 Penal Code Bill, this sanction is not used within the framework of clemency/mercy.
\end{abstract}

Keywords: Correctional institutions; criminals; social sanctions

\begin{abstract}
Abstrak
Lembaga Pemasyarkatan (Lapas) yang mengalami kelebihan penghuni terus terjadi di seluruh wilayah Indonesia. Berdasarkan data Direktorat Jenderal Pemasyarakatan, per Januari 2019, kelebihan penghuni di Lapas-lapas Indonesia telah menyentuh angka 101\%. Hal ini berbahaya dari berbagai sisi, mulai dari sisi kesehatan hingga psikologi. Karenanya, penelitian ini dilakukan untuk menganalisis ketentuan pidana kerja sosial dalam membatasi kelebihan penghuni di Lapas berdasarkan teori pemidanaan dan kriteria perbuatan pidana yang dapat dikenakan sanksi pidana kerja sosial. Penelitian ini merupakan penelitian normatif yang mengkaji hukum tertulis dari aspek teori, sejarah, filosofi, dan perbandingan, dengan menggunakan pendekatan konseptual dan yuridis. Berdasarkan analisis terhadap rumusan masalah, penelitian ini menyimpulkan, pertama, dengan kesesuaian pidana kerja sosial dan teori pemidanaan, pidana kerja sosial memiliki prospek untuk dapat diterapkan di Indonesia. Bahkan, jika peranannya sangat efektif dan efesien dalam mencapai tujuan pemidanaan, maka tidak menutup kemungkinan pidana kerja sosial menjadi pidana pokok yang bersifat tunggal dan dapat diterapkan pada delik-delik berat/serius serta sebagai syarat diterapkannya grasi. Hal itu dikarenakan keunggulan-keunggulan dari pidana kerja sosial, baik dari segi pendekatannya yang humanistis maupun ekonomis. Kedua, untuk ruang lingkupnya, pidana kerja sosial berfungsi sebagai sanksi alternatif dari pidana penjara singkat/ringan, yang kurang dari enam bulan, dan pidana denda ringan kategori pertama, yaitu maksimal sebesar sepuluh juta rupiah. Dalam RUU KUHP 2017, sanksi ini tidak diperuntukkan dalam kerangka grasi.
\end{abstract}

Kata-kata Kunci: Pidana kerja sosial, lembaga pemasyarakatan, narapidana 


\section{Pendahuluan}

Pidana kerja sosial (community service order) merupakan salah satu jenis sanksi pidana. Berdasarkan kajian teoritis dan praktis yang dilakukan oleh negara-negara Eropa, pidana kerja sosial dapat menjadi alternatif dari pidana perampasan kemerdekaan. ${ }^{1}$ Pidana kerja sosial dimaksudkan agar terpidana dapat terbebas dari rasa bersalah dan masyarakat dapat berperan serta secara aktif untuk memasyarakatkan terpidana dengan melakukan hal-hal yang bermanfaat. Munculnya jenis pidana ini juga dikarenakan adanya ketidakpuasan masyarakat terhadap pidana perampasan kemerdekaan, yang telah terbukti sangat merugikan baik terhadap individu yang dikenai pidana, maupun terhadap masyarakat. ${ }^{2}$

Pidana kerja sosial dalam sistem pemidanaan yang berasaskan konsepsi tersebut, sebagai wacana, perlu diterapkan untuk para narapidana agar memicu munculnya rasa malu terhadap pelaku. Upaya ini layak ditempuh untuk membangkitkan sisi kemanusiaan para pelaku kejahatan dan memunculkan budaya malu serta rasa bersalah. Saat ini, penjatuhan sanksi pidana yang paling diandalkan ialah sanksi pidana penjara. Penderitaan fisik, psikis, kehilangan anggota keluarga, harta benda, kehormatan, serta problem sosial dan kemanusiaan lainnya akibat kejahatan tidak menjadi perhatian dalam hukum pidana.

Pemikiran dalam Konsep Rancangan Undang-Undang tentang Kitab Undang-Undang Hukum Pidana (RUU KUHP) 2017 mulai bergeser tidak lagi memfokuskan pada upaya penjatuhan sanksi untuk pelanggar sebagai parameter keadilan, tetapi juga mengembangkan alternatif sanksi yang memikirkan kepentingan-kepentingan lain dari dampak kejahatan dengan memasukkan alternatif sanksi pidana, antara lain pidana pengawasan, kerja sosial, pembayaran ganti rugi, dan pemenuhan kewajiban adat. Sebagai perbandingan, sanksi pidana menurut Pasal 10 KUHP ada 2 macam, yaitu: ${ }^{3}$ pidana pokok yang terdiri atas pidana mati, pidana penjara, pidana kurungan, pidana tutupan, dan pidana denda, dan pidana tambahan yang terdiri atas pencabutan hak-hak tertentu, perampasan

\footnotetext{
1 Tongat, Pidana Kerja Sosial Dalam Pembaharuan Hukum Pidana Indonesia, Djambatan, Jakarta, 2001, hlm 7.

2 Muladi, Lembaga Pidana Bersyarat, Alumni, Bandung, 1992, hlm. 5.

${ }^{3}$ Moeljatno, Kitab Undang-Undang Hukum Pidana, Bumi Aksara, Jakarta, 2001, hlm. 5-6.
} 
barang-barang tertentu, dan pengumuman keputusan hakim. Sedangkan sanksi pidana menurut Pasal 66 Konsep RUU KUHP 2017, yaitu :4 pidana pokok yang terdiri atas pidana penjara, pidana tutupan, pidana pengawasan, pidana denda, dan pidana kerja sosial, dan pidana tambahan seperti dimaksud Pasal 65A Konsep RUU KUHP 2017 yang terdiri atas pencabutan hak-hak tertentu, perampasan barang tertentu dan/atau tagihan, pengumuman putusan hakim, pembayaran ganti kerugian, pencabutan surat ijin mengemudi, dan pemenuhan kewajiban adat setempat dan/atau kewajiban menurut hukum yang hidup dalam masyarakat. ${ }^{5}$

Dari penjabaran perbedaan pidana pokok pada KUHP dan RUU KUHP 2017 tersebut, terdapat perubahan yang signifikan yakni dalam hal ketentuan pidana mati yang di dalam KUHP menjadi salah satu hukuman pokok, namun tidak dapat ditemukan dalam jenis pidana pokok di dalam RUU KUHP 2017. Namun demikian, yang menarik perhatian untuk dibahas ialah mengenai jenis pidana baru, pidana kerja sosial.

Lembaga Pemasyarakatan (Lapas) yang mengalami kelebihan penghuninya terus terjadi di seluruh wilayah Indonesia. Berdasarkan data Direktorat Jenderal Pemasyarakatan (Ditjenpas), per Januari 2019, kelebihan penghuni di Lapas-lapas Indonesia menyentuh angka 101\%. Itu artinya sudah sangat berbahaya dari semua sisi, baik kesehatan maupun psikologis. Pidana penjara dengan sistem pemasyarakatan lebih berorientasi pada ide perlindungan/pembinaan dan perbaikan narapidana untuk dikembalikan lagi ke masyarakat ${ }^{6}$ yang dasarnya adalah nalar pembinaan (treatment, rehabilitation, correction). ${ }^{7}$ Lapas diharapkan bukan saja sebagai tempat untuk memidana orang semata, melainkan juga sebagai tempat untuk membina atau mendidik narapidana agar mereka setelah selesai menjalankan pidananya mempunyai kemampuan untuk menyesuaikan diri

\footnotetext{
${ }^{4}$ Rancangan Undang-Undang Kitab Undang-Undang Hukum Pidana 2017

5 Iskandar Wibawa, "Pidana Kerja Sosial dan Restitusi sebagia Alternatif Pidana Penjara dalam Pembaharuan Hukum Pidana Indonesia”, Jurnal Media Hukum, Vol.24, No.2, Desember 2017, hlm. 111.

${ }^{6}$ Barda Nawawi Arief, Bunga Rampai Kebijakan Hukum Pidana (Perkembangan Penyusunan Konsep KUHP Baru), Kencana Prenada Media Group, 2010, hlm. 238.

${ }^{7}$ Lidya Suryani Widayati, “Rehabilitasi Narapidana dalam Overcrowded Lembaga Pemasyarakatan”, Jurnal Negara Hukum, Vol.3, No.2, Desember 2012, hlm. 202. Lihat juga, Mardjono Reksodiputro, Kriminologi Dan Sistem Peradilan Pidana, Jakarta: Pusat Pelayanan Keadilan Dan Pengabdian Hukum (D/H Lembaga Kriminologi) Universitas Indonesia, 1987, hlm. 151.
} 
dengan kehidupan di luar Lapas sebagai warga negara yang baik dan taat pada hukum yang berlaku. ${ }^{8}$

Meskipun telah ada gagasan untuk menjadikan tujuan dari pidana penjara adalah pemasyarakatan dan meskipun sebutan dari rumah penjara sudah diganti dengan sebutan Lapas, namun, dalam praktek, gagasan tersebut tidak didukung oleh suatu konsepsi yang jelas dan sarana yang memadai. Selain itu, Lapas di Indonesia saat ini juga sudah kelebihan penghuni (over capacity). Kelebihan tingkat hunian tersebut merupakan permasalahan utama yang dihadapi Lapas dan Rumah Tahanan (Rutan) saat ini, terutama di Pulau Jawa. Tingkat hunian yang sudah melebihi daya tampung ini sangat menyulitkan baik dalam segi pembinaan, pengawasan, maupun pemeliharaan sanitasi para warga binaan itu sendiri. Untuk melihat seberapa besar permasalahan kelebihan penghuni, dapat dilihat melalui tabel di bawah ini:

Tabel 1: Perbandingan jumlah narapidana dan tahanan

\begin{tabular}{lcccc}
\hline \multicolumn{1}{c}{ Jumlah } & Desember & Desember & Desember & Desember \\
& 2015 & 2016 & 2017 & 2018 \\
\hline Tahanan & 57.547 & 65.544 & 70.736 & 72.106 \\
Narapidana & 119.207 & 139.006 & 161.345 & 183.274 \\
UPT & 447 & 477 & 513 & 521 \\
Kapasitas & 127.072 & 127.072 & 127.072 & 127.072 \\
Overcapacity & $39 \%$ & $61 \%$ & $83 \%$ & $101 \%$ \\
\hline
\end{tabular}

Sumber: Ditjenpas

Peningkatan angka tahanan dan narapidana terjadi tiap tahunnya. Meskipun jumlah Unit Pelaksanaan Teknis (UPT) bertambah, jumlah muatannya tidak ikut bertambah. Tentu saja, hal demikian tidak dapat membendung lonjakan penghuni Rutan dan Lapas. Tercatat pada Desember 2015 terdapat 447 UPT dengan kapasitas penghuni mencapai 127.072 orang. Tetapi, ternyata jumlah narapidana dan tahanan mencapai 176.754 orang. Hal ini mengakibatkan tingkat kelebihan kapasitas mencapai 39\%. Angka tersebut kemudian meningkat sampai Desember 2016, dengan peningkatan jumlah UPT mencapai 477 UPT. Kelebihan kapasitas

8 P.A.F. Lamintang dan Theo Lamintang, Hukum Penitensier: Edisi Kedua, Sinar Grafika, Jakarta, 2010, hlm. 
tetap terjadi dan meningkat menjadi $61 \%$, meskipun terjadi penambahan UPT menjadi 477 serta kapasitas yang tetap 127.072 penghuni. Pada data terakhir, melalui Sistem Database Pemasyarakatan (SPM) Ditjenpas Desember 2018, kelebihan kapasitas telah meningkat menembus angka 101\%. Hal ini dikarenakan jumlah penghuni Rutan dan Lapas yang mencapai 255.380 orang, berbanding kapasitas 521 UPT yang hanya mampu menampung 127.072 penghuni. ${ }^{9}$

Dari uraian singkat di atas, diketahui bahwa pidana penjara yang dijalankan sekarang tidak efektif dalam membina para narapidana. Oleh sebab itu, dibutuhkan alternatif pidana baru, salah satunya pidana kerja sosial yang tengah di gagas dalam RUU KHUP.

\section{Rumusan Masalah}

Berdasarkan latar belakang di atas, permasalahan dalam penelitian ini di rumuskan sebagai berikut: pertama, bagaimana ketentuan pelaksanaan pidana kerja sosial dalam membatasi kelebihan penghuni di Lapas? Dan kedua, apa kriteria perbuatan pidana yang dapat dikenakan pidana kerja sosial?

\section{Tujuan Penelitian}

Peneliti ini bertujuan untuk mendapatkan hasil yakni sebagai berikut: pertama, mengetahui ketentuan pelaksanaan pidana kerja sosial dalam membatasi kelebihan penghuni di Lapas dan kedua, mengetahui kriteria perbuatan pidana yang dapat dikenakan pidana kerja sosial.

\section{Metode Peneltian}

Penelitian ini adalah penelitian normative, yaitu penelitian yang mengkaji hukum tertulis dari aspek teori, sejarah, filosofi, perbandingan, stuktur dan komposisi, lingkup dan materi, hingga penjelasan umum dari pasal demi pasal, formalitas dan kekuatan mengikat suatu undang-undang, dan tidak mengikat aspek terapan atau implementasinya. ${ }^{10}$ Penelitian hukum normatif dilakukan dengan cara mengkaji hukum tertulis yang bersifat mengikat dari segala aspek

\footnotetext{
${ }^{9}$ http://smslap.ditjenpas.go.id/public/grl/current/monthly

${ }_{10}$ Abdulkadir Muhamad, Hukum dan Penelitian Hukum, PT. Citra Aditya Bakti, Bandung, 2004, hlm. 101.
} 
yang kaitannya dengan pokok bahasan yang diteliti. Penelitian ini dilakukan dengan menggunakan pendekatan konseptual dan yuridis.

\section{Hasil Penelitian dan Pembahasan}

\section{Ketentuan dalam Pelaksanaan Pidana Kerja Sosial}

Pidana kerja sosial masih merupakan konsep di dalam RUU KUHP. Tetapi, pidana kerja sosial di tiap-tiap negara hampir sama pelaksanaannya, yaitu tidak diberi upah, tidak dapat diwakilkan, tidak dapat diganti denda, dan pekerjaannya mempunyai manfaat bagi masyarakat. Tujuan pidana kerja sosial sama dengan tujuan pemasyarakatan sebagaimana diatur dalam Undang-Undang Nomor 12 Tahun 1995 tentang Pemasyarakatan, yaitu untuk membina narapidana dan menjadikannya manusia yang baik dan berguna bagi dirinya, sesamanya, dan nusa bangsa.

Ketentuan pelaksanaan pidana kerja sosial hanya akan dapat dilakukan apabila didukung oleh sistem nilai yang ada di masyarakat. Kebijakan legislatif dan pemerintah karenanya diperlukan. Dengan demikian, pemerintah harus lebih cermat melihat nilai-nilai hukum yang hidup dalam masyarakat untuk kemudian dimasukkan ke dalam hukum positif pada masa yang akan datang, seperti halnya pidana kerja sosial atau bentuk pidana baru lainnya yang sesuai dengan perasaan keadilan yang terdapat dalam masyarakat. Masyarakat juga perlu diberi pemahaman untuk menerima kehadiran narapidana yang bekerja di lingkungan sekitarnya dan tidak menghalangi pelaksanaan pidana kerja sosial.

Secara teoritis, pidana kerja sosial mengandung beberapa dimensi, yaitu:11 Pertama, pidana kerja sosial sebagai pidana perampasan kemerdekaan jangka pendek. Sesuai dengan dasar pemikiran yang melatarbelakangi lahirnya jenis pidana kerja sosial, yaitu untuk mencari alternatif dari pidana perampasan kemerdekaan untuk jangka pendek. Sekalipun dengan penerapan yang berbeda, sebagai pidana mandiri atau sebagai syarat berkaitan dengan penjatuhan pidana

${ }^{11}$ Muladi, Kapita Selekta Sistem Peradilan Pidana, Badan Penerbit Universitas Diponegoro, 1995, hlm. 139. Lihat juga, Gatot Sugiharto, "Relevansi Kebijakan Penetapan Pidana Kerja Sosial dalam Sistem Pemidanaan di Indonesia”, Jurnal Ilmu Hukum Novelty, Vol.7, No.1, Februari 2016, hlm. 90-91 
bersyarat, kecenderungan internasional yang terjadi adalah sama, yaitu menjadikan pidana kerja sosial sebagai alternatif pidana perampasan kemerdekaan untuk jangka pendek. Kedua, pidana kerja sosial sebagai alternatif sanksi apabila denda tidak dibayar. Pidana kerja sosial dapat menggantikan pidana penjara pengganti apabila terpidana denda gagal membayar pidana dendanya. Jadi, apabila ada seseorang terdakwa oleh hakim dijatuhi hukuman denda kemudian tidak dapat membayar denda tersebut, maka sebagai ganti tidak terbayarnya denda terpidana harus menjalani pidana pengganti. Dalam pelaksanaannya, pidana penjara pengganti (denda) inilah yang dapat diganti dengan pidana kerja sosial. Ketiga, pidana kerja sosial dalam kerangka grasi. Di beberapa negara Eropa, pidana kerja sosial ini dapat menjadi syarat ditetapkannya grasi. Belanda misalnya, grasi dapat dijatuhkan atau diterapkan kepada seorang terpidana dengan syarat terpidana harus melakukan pidana kerja sosial.

Mekanisme dan ketentuan penjatuhan pidana kerja sosial antara lain dikemukakan sebagi berikut: ${ }^{12}$

\section{Terpidana kerja sosial tidak perlu tinggal di Lapas.}

Inilah perbedaan mendasar dari pidana penjara. Seseorang yang oleh hakim diputus dengan hukuman pidana kerja sosial tetap tinggal di kediaman masingmasing. Mereka hanya diwajibkan bekerja pada jam-jam tertentu tanpa dikomersialkan. ${ }^{13}$ Pelaksanaannya dilakukan dengan diawasi oleh dewan pengawas. ${ }^{14}$

\section{Kategori tindak pidana.}

Secara umum, di negara-negara Eropa, dpersyaratkan bahwa pidana kerja sosial hanya dapat diterapkan terhadap tindak pidana yang tidak terlalu berat. Persyaratan yang mungkin ditetapkan dalam penerapan pidana kerja sosial adalah persyaratan yang berkaitan dengan si pelaku itu sendiri, misalnya usia pelaku dan criminal record dari pelaku. Dalam RUU KUHP 2017, terkait dengan syarat tindak pidana yang bisa diganjar dengan pidana kerja sosial, terdapat di dalam Pasal 88

12 Tongat, Pidana Kerja..., Op. Cit., hlm. 10-12.

13 Ida Ayu Made Merta Dewi, Yuwono, "Relevansi Pidana Kerja Sosial dalam Perspektif Pembaharuan Hukum Pidana”, e-Jurnal Ilmu Hukum Kertha Wicara, Vol. 04, No. 03, September 2015, hlm. 3.

${ }^{14}$ Pasal 88 ayat (3) Rancangan Undang-Undang Kitab Undang-Undang Hukum Pidana 2017 
ayat (1) yang menyebutkan, jika pidana penjara yang akan dijatuhkan tidak lebih dari enam bulan atau pidana denda tidak lebih dari pidana denda kategori I, maka pidana penjara atau pidana denda tersebut dapat diganti dengan pidana kerja sosial. 15

Pidana kerja sosial hanya diberikan pada tindak pidana ringan yang hukuman pidananya pendek. Melihat fakta empiris pidana penjara saat ini, maka pidana kerja sosial lebih bermanfaat untuk para nara pidana. Selain itu, jika ditinjau dari filosofi tujuan pemidanaan, maka pidana kerja sosial dirasa setimpal dengan tindak pidana yang dilakukan, yaitu tindak pidana ringan dengan jangka hukuman pendek.

Penerapan pidana kerja sosial secara umum sama dengan pelaksanaan di negara-negara Eropa yang sudah menerapkan jenis pidana ini. Pidana kerja sosial hanya dapat diterapkan dalam jenis tindak pidana tertentu. Umumnya, negaranegara di Eropa mempersyaratkan, pidana kerja sosial hanya dapat diterapkan terhadap tindak pidana yang tidak terlalu berat. Dengan kata lain, pidana kerja sosial tidak dapat dijatuhkan atau diterapkan terhadap jenis tindak pidana berat.

Penerapan pidana sosial untuk tindak pidana ringan yang ancaman hukumannya relatif pendek sesuai dengan tujuan pemansyarakatan yaitu untuk membina kembali seorang yang sudah tersesat, dengan harapan agar ia sanggup menjadi manusia yang baik dan berguna bagi dirinya, bagi sesamanya, dan bagi nusa dan bangsanya. Pendeknya, pidana kerja sosial sejalan dengan ide pemasyarakatan yang memiliki tujuan untuk kembali menjadikan seorang narapidana menjadi manusia yang utuh. ${ }^{16}$ Pidana kerja sosial yang dilakukan mendorong terpidana agar mengaktualisasikan nilai-nilai kemanusiaannya sehingga ia akan mampu mengendalikan kecenderungan-kecenderungan yang negatif.

15 Yang dimaksud dengan kategori I disebutkan dalam Pasal 82 ayat (3) Rancangan Undang-Undang Kitab Undang-Undang Hukum Pidana 2017 bahwa besarnya denda untuk kategori I adalah Rp. 6.000.000,00 (enam juta rupiah).

${ }^{16}$ Taufan Purwadiyanto, “Analisis Pidana Kerja Sosial dalam Hukum Positif Indonesia”, Lex Administratum, Vol.III, No.8, Oktober 2015, hlm. 158. 
Selain itu, yang perlu menjadi catatan adalah berkaitan dengan catatan kejahatan pelaku. Pidana kerja sosial pada umumnya tidak akan diterapkan terhadap pelaku kejahatan yang mempunyai catatan kejahatan (criminal record) yang tidak baik. Di Perancis misalnya, pidana kerja sosial tidak akan diterapkan terhadap para residivis. Pidana kerja sosial hanya dapat diterapkan terhadap residivis apabila dikaitkan dengan pidana bersyarat dan bukan sebagai pidana yang mandiri

\section{Jumlah jam pidana kerja sosial}

Pada umumnya, ketentuan yang berkaitan dengan pengaturan tentang pidana kerja sosial juga menyangkut pengaturan tentang jam kerja minimum dan maksimum pidana kerja sosial yang di setiap negara bervariasi. Berkaitan dengan jumlah jam pidana kerja sosial, dijelaskan dalam Pasal 88 ayat, (4), (5), (6), dan (7) RUU KUHP 2017 yang berbunyi sebagai berikut;

(4)Pidana kerja sosial dijatuhkan paling lama: a. dua ratus empat puluh jam bagi terdakwa yang telah berusia 18 (delapan belas) tahun ke atas; dan b. seratus dua puluh jam bagi terdakwa yang berusia di bawah 18 (delapan belas) tahun.

(5)Pidana kerja sosial sebagaimana dimaksud pada ayat (3) paling singkat 7 (tujuh) jam.

(6)Pelaksanaan pidana kerja sosial dapat diangsur dalam waktu paling lama 12 (dua belas) bulan dengan memperhatikan kegiatan terpidana dalam menjalankan mata pencahariannya dan/atau kegiatan lain yang bermanfaat.

(7)Jika terpidana tidak memenuhi seluruh atau sebagian kewajiban menjalankan pidana kerja sosial tanpa alasan yang sah maka terpidana diperintahkan:

a) mengulangi seluruh atau sebagian pidana kerja sosial tersebut;

b) menjalani seluruh atau sebagian pidana penjara yang diganti dengan pidana kerja sosial tersebut; atau

c) membayar seluruh atau sebagian pidana denda yang diganti dengan pidana kerja sosial atau menjalani pidana penjara sebagai pengganti pidana denda yang tidak dibayar.

Ketentuan mengenai jam kerja di atas memiliki semangat kemanusiaan dengan tidak melupakan esensi pidana, yaitu memberikan manfaat untuk mayarakat. Jika dibandingkan dengan beberapa negara yang telah menerapkan pidana kerja sosial, waktunya terbilang sangat singkat. Misalnya, di Denmark, 
enam sampai delapan bulan, sedangkan di Norwegia dan Luxemburg, sembilan sampai dua belas bulan, dan di Belanda dan Portugal empat bulan.

Hemat penulis, waktu yang diberikan oleh RUU KUHP 2017 sebagaimana ketentuan pasal-pasal di atas relatif manusiawi. Pidana kerja sosial yang dilakukan bukanlah bersifat kerja paksa, apalagi pada ketentuan ayat (6) disebutkan bahwa pelaksanaannya bisa diangsur dengan melihat kegiatan terpidana. Ketentuan ini semakin mempertegas pembinaan narapidana secara manusiawi dengan tetap menjunjung tinggi hak dan martabatnya. Selain itu, ketentuan pidana kerja sosial yang diatur dalam RUU KUHP 2017 juga mempertimbangkan usia pelaku, yaitu adanya larangan bagi pelaku yang masih di bawah umur, yang berdasarkan hukum perburuhan dilarang untuk melakukan kerja. Dengan demikian, berkaitan dengan usia pelaku dalam penerapan pidana kerja sosial, ketentuannya telah memperhatikan hak-hak pelaku, terutama berkaitan dengan pelaku anak-anak.

\section{Persetujuan terpidana.}

Terkait dengan persetujuan terpidana, dalam Pasal 88 ayat (2) RUU KUHP 2017, diatur bahwa dalam penjatuhan pidana kerja sosial, wajib dipertimbangkan hal-hal sebagai berikut: a. pengakuan terdakwa terhadap tindak pidana yang dilakukan; b. usia layak kerja terdakwa sesuai dengan ketentuan peraturan perundang-undangan; c. persetujuan terdakwa sesudah dijelaskan mengenai tujuan dan segala hal yang berhubungan dengan pidana kerja sosial; d. riwayat sosial terdakwa; e. perlindungan keselamatan kerja terdakwa; f. keyakinan agama dan politik terdakwa; dan g. kemampuan terdakwa membayar pidana denda.

Adanya persetujuan dari terdakwa juga sesuai dengan konsep hukuman kerja sosial untuk tindak pidana ringan. Pelaksanaan jenis hukuman ini harus mendapatkan persetujuan dari terpidana. Keharusan persetujuan terpidana, antara lain disinggung dalam Konvensi Jenewa 1930 (Forced Labour Convention), Traktat Rorneo 1950 (Convention for the Protection of Human Rights and Fundamental Freedom), 
Konvensi Jenewa 1957 (The Abolition of Forced Labour Convention), dan Kovenan Hak-Hak Sipil dan Politik. ${ }^{17}$

\section{Isi pidana kerja sosial.}

Hakim yang menjatuhkan pidana kerja sosial di pengadilan hanya menetapkan jumlah jam dan jangka waku yang harus dipenuhi. Sementara pelaksanaanya secara teknis, yang berkaitan dengan tempat pidana kerja sosial harus dijalani, berapa jam pidana kerja sosial harus dijalankan setiap harinya, dan sebagainya, dilakukan oleh probation service. Dalam pelaksanaan pekerjaan sosial atau pidana sosial, pelaku idealnya terlibat dalam kegiatan yang berinteraksi secara langsung dengan masyarakat. Hal ini sejalan dengan tujuan utama dari pelayanan masyarakat yang mendorong pelaku untuk bersosialisasi dan mengenal isu-isu tentang komunitas masyarakat. Tujuan akhir dari pidana kerja sosial ini adalah diharapkan pelaku mengalami proses "humanisasi" yang dapat meningkatkan kepercayaan dan kepribadiannya, meningkatkan kecerdasan, mendapatkan kembali kepercayaan masyarakat terhadap dirinya, serta menyampaikan pesan kepada masyarakat bahwa dia dan pelaku lainnya hanya manusia biasa yang dapat membuat kesalahan dan dapat pula berubah menjadi manusia yang lebih baik. Pidana kerja sosial juga membatasi gerak pelaku melalui perintah pelayanan masyarakat, sehingga secara bersamaan mencegah mereka dari perbuatan yang mengarah pada perbuatan mengulangi tindak pidana.

\section{Kegagalan menjalani pidana kerja sosial}

Seorang terpidana yang gagal menjalani pidana kerja sosial akan membawa akibat tertentu berupa. Pertama, apabila pidana kerja sosial berupa pidana yang mandiri, maka akibat kegagalan terpidana menjalani pidana kerja sosial dapat berupa dijatuhi denda sampai batas tertentu, mengulangi lagi pelaksanaan pidana kerja sosial, atau dikenakan pidana alternatif yang lain. Kedua, apabila pidana kerja sosial ditetapkan dalam kaitannya dengan pidana bersyarat (suspended sentence), maka kegagalan terpidana menjalani pidana kerja sosial dapat mengakibatkan

17 Diakses dari http://www.hukumonline.com/berita/baca/hol19996/hukuman-kerja-sosialjadialternatif-pidana-penjara-dan-denda pada tanggal 6 April 2017. 
diterapkannya pidana penjara yang ditunda. Akibat dari kegagalan, terpidana juga dapat diharuskan untuk mengulangi pidana kerja sosial itu.

Mekanisme dan ketentuan pidanan kerja sosial yang terdapat dalam RUU KUHP 2017 sejalan dengan konsep dan filosofi tujuan pemidanaan. Selain itu, pidana kerja sosial juga merupakan "antitesa" terhadap konsep pidana penjara yang sudah mendapat kritikan tajam.

\section{Kriteria Perbuatan Pidana yang dapat Dikenakan Pidana Kerja Sosial}

Pidana kerja sosial sebagai suatu pidana sudah tidak asing lagi di beberapa negara karena negara-negara tertentu, khususnya seperti yang ada di benua Eropa, telah sejak dulu menerapkan pidana seperti itu. Namun, berbeda halnya dari Indonesia, pidana kerja sosial terbilang sesuatu yang masih baru dan masih asing didengar. Pidana kerja sosial di Indonesia masih berupa konsep/rancangan dalam RUU KUHP Indonesia yang tidak kunjung selesai-selesai dibahas.

Memang diperlukan adanya sanksi-sanksi baru ataupun alternatif bagi para pelaku kejahatan di Indonesia saat ini, mengingat bentuk dan jenis kejahatan yang mulai beragam dan makin meningkat, seiring berkembangnya zaman. Kejahatankejahatan demikian, baik kejahatan yang terjadi secara konvensional maupun kejahatan dengan perangkat teknologi yang canggih.

Pidana kerja sosial merupakan bentuk pidana badan. Pidana tersebut dijalani oleh terpidana dengan melakukan pekerjaan sosial yang ditentukan dan dengan syarat-syarat tertentu. Sasaran dari objek pidana tersebut adalah dikenakan pada fisik/tenaga si terpidana/pelaku. Dalam Penjelasan Umum RUU KUHP 2017 juga ditegaskan bahwa Penyusunan KUHP Nasional dalam rangka menggantikan KUHP peninggalan pemerintah kolonial Belanda dengan segala perubahannya merupakan salah satu usaha dalam rangka pembangunan hukum nasional. Usaha tersebut dilakukan secara terarah dan terpadu agar dapat mendukung pembangunan nasional di berbagai bidang, sesuai dengan tuntutan pembangunan serta tingkat kesadaran hukum dan dinamika yang berkembang dalam masyarakat. Berdasarkan atas landasan yang terkandung dalam konsideran RUU KUHP 2017, reformulasi atas pengaturan hukum pidana yang dilakukan meliputi 
penentuan tindak pidana (kriminalisasi) yang sangat jauh berbeda dari KUHP sekarang.

Tercatat ada 743 pasal dalam RUU KUHP 2017 yang 513-nya merupakan pasal-pasal mengenai tindak pidana dan selebihnya merupakan pasal-pasal ketentuan umum. Adanya perubahan yang cukup mendasar dari konsep awal sampai dengan konsep yang terakhir menunjukkan bahwa persoalan pemberian sanksi dalam RUU KUHP 2017 selalu disesuaikan dengan perkembangan kondisi kehidupan berbangsa dan bernegara. Materi baru yang diatur dalam RUU KUHP adalah terkait sanksi pidana kerja sosial. Pidana kerja sosial merupakan bentuk pidana yang dijalankan oleh terpidana dengan melakukan pekerjaan sosial yang ditentukan. Dalam wacana ilmu hukum pidana, istilah "pidana kerja sosial" kemudian lazim diterjemahkan ke dalam bahasa Inggris dengan istilah Community Service Order. 18

Menurut Barda Nawawi, kritik yang moderat terhadap pidana penjara dapat dikelompokkan dalam tiga kritik yaitu: ${ }^{19}$

1. Kritik dari sudut strafmodus, yaitu melihat dari sudut pelaksanaan pidana penjara, sistem pembinaan atau treatment, dan kelembagaan atau institusinya.

2. Kritik dari sudut strafmaat yang melihat dari sudut lamanya pidana penjara, khususnya ingin membatasi atau mengurangi penggunaan pidana penjara jangka pendek.

3. Kririk dari sudut straftshort yang ditujukan terhadap penggunaan atau penjatuhan pidana penjara yang dilihat sebagai jenis pidana, yaitu adanya kecenderungan untuk mengurangi atau membatasi penjatuhan pidana penjara secara limitatif dan selektif.

Mengenai jenis-jenis pemidanaan, dalam KUHP dikenal dua jenis pidana yang diatur dalam Pasal 10 KUHP yakni: pidana pokok yang terdiri atas pidana mati, pidana penjara, pidana kurungan, pidana tutupan, dan pidana denda, dan pidana tambahan yang terdiri atas pencabutan hak-hak tertentu, perampasan barang-barang tertentu, dan pengumuman keputusan hakim. Dari jenis-jenis pemidanaan tersebut, tidak dikenal jenis "pidana kerja sosial". Beda halnya di

18 Tongat, Pidana Kerja..., Op. Cit., hlm. 7 hlm. 34 .

${ }^{19}$ Barda Nawawi Arief, Kapita Selekta Hukum Pidana, Cetakan Pertama, Citra Aditya Bakti, Bandung, 2003, 
beberapa negara seperti Belanda dan Inggris yang memang mengenal jenis hukuman kerja sosial. KUHP Belanda versi 1996 pada judul punishment juga mencantumkan jenis hukuman community services. Pasal 22 ayat (1) huruf c KUHP Belanda versi bahasa Inggris mencantumkan rumusan berikut, "the judge may only impose a penalty of community service upon request from the eccused to perform such work." 20

Di Indonesia, pidana kerja sosial dikenal sejak dicantumkan dalam konsep RUU KUHP. Pada Pasal 66 ayat (1) RUU KUHP 2017, disebutkan bahwa i) pidana pokok terdiri atas pidana penjara, pidana tutupan, pidana pengawasan, pidana denda, dan pidana kerja sosial, dan ii) pidana tambahan seperti dimaksud Pasal 65A Konsep RUU KUHP 2017 yang terdiri atas pencabutan hak-hak tertentu, perampasan barang tertentu dan/atau tagihan, pengumuman putusan hakim, pembayaran ganti kerugian, pencabutan surat ijin mengemudi, dan pemenuhan kewajiban adat setempat dan/atau kewajiban menurut hukum yang hidup dalam masyarakat. Penjelasan lebih lanjut mengenai pidana kerja sosial dalam RUU KUHP 2017 diatur dalam Pasal 88 ayat (1) yang menyebutkan, jika pidana penjara yang akan dijatuhkan tidak lebih dari enam bulan atau pidana denda tidak lebih dari pidana denda Kategori I, maka pidana penjara atau pidana denda tersebut dapat diganti dengan pidana kerja sosial.

Berdasarkan ketentuan pasal tersebut, dapat disimpulkan bahwa pidana kerja sosial tidak dapat dijatuhkan dalam setiap tindak pidana yang terjadi. Secara prinsipil, pidana kerja sosial merupakan alternatif dari tindak pidana ringan dan dikenakan terhadap pidana perampasan kemerdekaan jangka pendek. Konsepsi ini bertolak dari pemikiran bahwa pidana kerja sosial merupakan jenis pidana yang akan dijatuhkan kepada para pelaku tindak pidana yang tidak terlalu berat. Ini berarti pidana kerja sosial sekali-kali tidak dapat dijatuhkan manakala tindak pidana yang dilakukan oleh terdakwa adalah jenis tindak pidana berat. Berdasarkan ketentuan Pasal 88 RUU KUHP 2017, pidana kerja sosial dapat

\footnotetext{
20 Diakses dari http://www.hukumonline.com/berita/baca/hol19996/hukuman-kerja-sosialjadialternatif-pidana-penjara-dan-denda
} 
dijatuhkan dalam hal: 1. Hakim mempertimbangkan akan menjatuhkan pidana penjara yang tidak lebih dari enam bulan. Dengan demikian, dalam hal hakim mempertimbangkan untuk menjatuhkan pidana penjara lebih dari enam bulan, maka pidana kerja sosial tidak dapat dijatuhkan. Ketentuan ini didasarkan pada falsafah bahwa pidana kerja sosial memang merupakan alternatif dari pidana perampasan kemerdekaan jangka pendek. 2. Hakim mempertimbangkan akan menjatuhkan pidana denda dengan tidak melebihi kategori atau maksimum seratus lima puluh ribu rupiah.

Sementara itu, berdasarkan ketentuan Pasal 88 ayat (2) RUU KUHP 2017 dinyatakan, dalam hal hakim akan menjatuhkan pidana kerja sosial perlu diperhatikan berbagai hal. Berbagai persyaratan tersebut dimaksudkan agar pidana kerja sosial benar-benar dapat dijalankan. Tentu saja tidak semua perbuatan pidana dapat dikenakan atau diberikan pidana kerja sosial, adapun kriteria dalam penjatuhan sanksi dalam pidana kerja sosial adalah sebagai berikut: 1. Pidana kerja sosial dapat dijatuhkan kepada terdakwa yang melakukan tindak pidana yang diancam dengan pidana penjara di bawah lima tahun dan hakim menjatuhkan pidana tidak lebih dari enam bulan penjara atau pidana denda tidak lebih dari Kategori I. 2. Dalam penjatuhan pidana kerja sosial sebagaimana dimaksud di atas, wajib dipertimbangkan hal-hal sebagai berikut: a) pengakuan terdakwa terhadap tindak pidana yang dilakukan; b) usia layak kerja terdakwa sesuai dengan ketentuan peraturan perundang-undangan; c) persetujuan terdakwa sesudah dijelaskan mengenai tujuan dan segala hal yang berhubungan dengan pidana kerja sosial; d) riwayat sosial terdakwa; e) perlindungan keselamatan kerja terdakwa; f) keyakinan agama dan politik terdakwa; dan g) kemampuan terdakwa membayar pidana denda. 3. Pelaksanaan pidana kerja sosial tidak boleh dikomersialkan. 4. Pidana kerja sosial dijatuhkan paling lama: a) dua ratus empat puluh jam bagi terdakwa yang berusia delapan belastahun atau lebih; dan b) seratus dua puluh jam bagi terdakwa yang berusia di bawah delapan belas tahun. 5. Pidana kerja sosial sebagaimana dimaksud pada poin tiga, paling singkat dilaksanakan selama tujuh jam. 6. Pelaksanaan pidana kerja sosial dapat diangsur dalam waktu paling lama dua belas bulan dengan memperhatikan kegiatan terpidana dalam menjalankan mata pencahariannya dan/atau kegiatan lain yang bermanfaat. 7. Jika 
terpidana tidak memenuhi seluruh atau sebagian kewajiban menjalankan pidana kerja sosial tanpa alasan yang sah, maka terpidana diperintahkan: a) mengulangi seluruh atau sebagian pidana kerja sosial tersebut; b) menjalani seluruh atau sebagian pidana penjara yang diganti dengan pidana kerja sosial tersebut; atau c) membayar seluruh atau sebagian pidana denda yang diganti dengan pidana kerja sosial atau menjalani pidana penjara sebagai pengganti pidana denda yang tidak dibayar.

Adanya kriteria dalam pelaksanaan ataupun pemberian sanksi pidana kerja sosial, tentu alternatif ini dapat mengurangi kelebihan penghuni di Lapas yang selama ini menjadi masalah yang cukup rumit dalam peneyelesaiannya. Terdapat berbagai macam kerja sosial yang dijadikan hukuman bagi para pelaku kejahatan. Misalnya, seperti membersihkan toilet umum, membersihkan parit atau selokan, menyapu jalanan, bertugas di panti jompo, dan lain sebagainya. Kerja sosial ini dilakukan secara rutin selama periode hukuman berlangsung. Hakim memvonis sekian bulan untuk menjalani pidana kerja sosial. Melalui pidana kerja sosial, terpidana tidak akan berusaha untuk mengulangi kejahatan yang pernah dilakukan karena jika melakukan tindak pidana lagi, maka pengadilan akan menjatuhkan pidana penjara dan denda.

Anggota tim perumus RUU KHUP 2017, Enny Nurbaningsih, menjelaskan penambahan sanksi pidana kerja sosial sebagai hukuman alternatif bertujuan untuk mengurangi persoalan kelebihan kapasitas di Lapas ataupun penerapan sanksi pidana kerja sosia nantinya menjadi kewenangan hakim saat memutus perkara. Menurut Mudzakir, pelaksanaan pidana kerja sosial akan melibatkan yayasan yang mengelola panti asuhan, panti jompo, dan lain-lain. Terbuka juga peluang untuk bekerja sama dengan pemerintah daerah untuk menggunakan fasilitas umum sebagai tempat kerja sosial. Sementara Lapas bertugas mendistribusikan narapidana yang akan menjalaninya.

\section{Penutup}

Dari pembahasan mengenai pelaksanaan dan kriteria perbuatan pidana dalam pidana kerja sosial, ditarik kesimpulan sebagai berikut. Pertama, pidana 
kerja sosial memenuhi unsur sanksi pidana yang dikenakan kepada seseorang yang telah melakukan tindak pidana menurut undang-undang, yaitu kepada seseorang yang terbukti melanggar suatu peraturan hukum dan dapat dimintai pertanggungjawaban, sebagaimana yang telah ditetapkan dalam peraturan hukum suatu negara. Pidana kerja sosial mengandung orientasi pencapaian tujuan-tujuan pidana berupa pelajaran (pembalasan/ penderitaan), pendidikan kepada si pelaku dan masyarakat umum, dan upaya pencegahan, baik umum maupun khusus, untuk perlindungan individu dan masyarakat, dengan harapan tercapainya ketertiban dalam masyarakat.

Kedua, pidana kerja sosial merupakan sanksi alternatif dari pidana penjara singkat/ringan, yang kurang dari enam bulan, dan pidana denda ringan kategori pertama, yaitu maksimal sebesar sepuluh juta rupiah. Pelaksanaan pidana kerja sosial tidak boleh dikomersialkan. Pidana kerja sosial dalam RUU KUHP 2017 tidak diperuntukkan dalam kerangka grasi. Pengaturan syarat-syarat khusus dalam penetapan dan penjatuhan pidana kerja sosial dalam RUU KUHP 2017 adalah sebagai berikut: i) bahwa pidana kerja sosial dijatuhkan pada delik-delik yang tidak telalu berat/delik ringan. Namun, pidana kerja sosial memiliki peluang untuk dijatuhkan pada semua delik, selama tidak ada pengaturan batas minimum ancaman pidana pada suatu delik yg diatur. Bahkan, tidak menutup kemungkinan pidana kerja sosial dapat diterapkan pada delik extra ordinary crime seperti korupsi, namun harus diteliti lebih lanjut khusus mengenai hal ini; ii) bahwa pidana kerja sosial yang akan dijatuhkan harus memperhatikan pelaku, khususnya dari aspek usia pelaku, jenis kelamin, criminal records, riwayat sosial pelaku, persetujuan si pelaku dalam menerima penjatuhan pidana kerja sosial itu sendiri, kemampuan/kesanggupan pelaku dalam bekerja, keyakinan si pelaku, jaminan dan perlindungan dari keselamatan kerja si pelaku selama menjalani pidana kerja sosial, serta kemampuan pelaku dalam membayar denda; iii) bahwa waktu pidana kerja sosial dijatuhkan paling lama dua ratus empat puluh jam bagi terdakwa yang telah berusia delapan belas tahun ke atas dan seratus dua puluh jam bagi terdakwa yang berusia di bawah delapan belas tahun. Pidana kerja sosial paling singkat adalah tujuh jam. Pelaksanaan pidana kerja sosial dapat diangsur dalam waktu 
paling lama dua belas bulan dengan memperhatikan kegiatan terpidana dalam menjalankan mata pencahariannya dan/atau kegiatan lain yang bermanfaat.

Hasil dari uraian di atas penulis merekomendasi yakni pidana kerja sosial yang sudah ada di dalam RUU KUHP 2017 memberi harapan mengenai perubahan dalam sistem pidana dan pemidanaan Indonesia. Namun, harus dilakukan beberapa pembenahan agar tidak terjadi ketidaksinkronan dengan peraturan perundang-undangan lainnya yang terkait serta efektif-efesien dalam tataran pelaksanaanya nanti. Pembenahan-pembenahan tersebut diantaranya: Pertama, lokasi pelaksanaan pidana kerja sosial atau publik servis sebaiknya dilakukan di tempat kejahatan terjadi, khususnya delik gangguan ketertiban umum. Kemudian, pemilihan lokasi harus disesuaikan dengan masyarakat dan keadaan umum di sekitarnya sebagai ajang hidup narapidana nanti. Kedua, penyusunan dan penetapan aturan pelaksanaan pidana kerja sosial, hukum acaranya, atau pedoman pelaksanaan pidananya. Ketiga, kebijakan formulasi pidana kerja sosial dalam RUU KUHP 2017 sebaiknya memperhatikan pengalaman-pengalaman dari beberapa negara yang telah menerapkan pidana kerja sosial dan memperhatikan kelemahan dan keberhasilan dari penerapan pidana kerja sosial, sehingga dalam penerapannya kelak, ia dapat meminimalisasi kendala dari penerapan pidana kerja sosia.

\section{Daftar Pustaka}

\section{Buku}

Arief, Barda Nawawi, Bunga Rampai Kebijakan Hukum Pidana (Perkembangan Penyusunan Konsep KUHP Baru), Kencana Prenada Media Group, 2010.

Arief, Barda Nawawi, Kapita Selekta Hukum Pidana, Cetakan Pertama, Citra Aditya Bakti, Bandung, 2003.

Lamintang, P.A.F. dan Lamintang, Theo, Hukum Penitensier: Edisi Kedua, Sinar Grafika, Jakarta, 2010

Moeljatno, Kitab Undang-Undang Hukum Pidana, Bumi Aksara, Jakarta, 2001.

Muhamad, Abdulkadir, Hukum dan Penelitian Hukum, PT. Citra Aditya Bakti, Bandung, 2004. 
Muladi, Kapita Selekta Sistem Peradilan Pidana, Badan Penerbit Universitas Diponegoro, 1995.

Muladi, Lembaga Pidana Bersyarat, Alumni, Bandung, 1992.

Reksodiputro, Mardjono, Kriminologi Dan Sistem Peradilan Pidana, Jakarta: Pusat Pelayanan Keadilan Dan Pengabdian Hukum (D/H Lembaga Kriminologi) Universitas Indonesia, 1987.

Tongat, Pidana Kerja Sosial Dalam Pembaharuan Hukum Pidana Indonesia, Djambatan, Jakarta, 2001.

\section{Jurnal}

Dewi, Ida Ayu Made Merta, Yuwono, "Relevansi Pidana Kerja Sosial dalam Perspektif Pembaharuan Hukum Pidana", e-Jurnal Ilmu Hukum Kertha Wicara, Vol. 04, No. 03, September 2015.

Purwadiyanto, Taufan, "Analisis Pidana Kerja Sosial dalam Hukum Positif Indonesia", Lex Administratum, Vol. III, No. 8, Oktober 2015.

Sugiharto, Gatot, "Relevansi Kebijakan Penetapan Pidana Kerja Sosial dalam Sistem Pemidanaan di Indonesia", Jurnal Ilmu Hukum Novelty, Vol. 7, No. 1, Februari 2016

Wibawa, Iskandar, "Pidana Kerja Sosial dan Restitusi sebagia Alternatif Pidana Penjara dalam Pembaharuan Hukum Pidana Indonesia", Jurnal Media Hukum, Vol. 24, No. 2, Desember 2017

Widayati, Lidya Suryani, "Rehabilitasi Narapidana dalam Overcrowded Lembaga Pemasyarakatan", Jurnal Negara Hukum, Vol. 3, No. 2, Desember 2012

\section{Peraturan}

Rancangan Undang-Undang Kitab Undang-Undang Hukum Pidana 2017

\section{Internet}

http://smslap.ditjenpas.go.id/public/grl/current/monthly

http://www.hukumonline.com/berita/baca/hol19996/hukuman-kerjasosialjadi-alternatif-pidana-penjara-dan-denda 